\title{
Pertanggungjawaban Pidana Kecelakaan Lalu Lintas Karena Penggunaan Smartphone Saat Mengemudi
}

\author{
Noor Camilla Jasmine \\ Fakultas Hukum, Universitas Muhammadiyah Yogyakarta \\ Email : camillajasminee97@gmail.com
}

\section{Info Artikel}

\section{Kata Kunci :}

Kecelakaan,

Lalu Lintas,

Pertanggungjawaban Pidana,

Smartphone,

Tindak Pidana.

\section{Perjalanan Artikel :}

Diterima : 21 Januari 2020

Direview : 01 Februari 2020

Direvisi : 10 Maret 2020

Dipublikasikan : Maret 2020

DOI: 10.18196/ijclc.v1i1.9155

\begin{abstract}
Abstrak
Penggunaan smartphone merupakan salah satu perkembangan teknologi yang harus disikapi dengan bijak. Kurang bijaknya pengemudi yang menggunakan smartphone saat mengemudi dapat membahayakan keselamatan dirinya ataupun pengguna jalan lain karena dikhawatirkan akan menyebabkan kecelakaan. Pokok permasalahan dalam penelitian ini adalah bagaimana bentuk tindak pidana kecelakaan lalu lintas yang disebabkan karena penggunaan smartphone saat mengemudi dan bagaimana ketentuan perundang-undangan yang mengatur mengenai pertanggungjawaban pidana terhadap pengendara yang menggunakan smartphone saat mengemudi dan menyebabkan kecelakaan sesuai dengan undang-undang yang berlaku. Jenis penelitian yang digunakan adalah normatif, menggunakan bahan hukum penelitian yaitu bahan hukum primer, sekunder dan tersier. Teknik pengumpulan dari penelitian ini adalah studi pustaka serta melakukan wawancara kepada para pihak untuk mendukung penelitian ini. Setelah dilakukan pengumpulan bahan penelitian maka hasil tersebut diolah dan di analisis secara deskriptif kualitatif. Hasil penelitian yang telah dilakukan mengkategorikan penggunaan smartphone ini kedalam dua bentuk tindak pidana yaitu kesengajaan dengan sadar kemungkinan atau kealpaan, didalam pertanggungjawaban pidananya maka dapat dikenakan sanksi pidana jika terjadi kecelakaan yang terdapat didalam Pasal 310 dan Pasal 311 selain itu Pengemudi juga dapat dikenakan sanksi pelanggaran yang terdapat didalam Pasal 283 Undang-Undang Nomor 22 Tahun 2009 Tentang Lalu Lintas dan Angkutan Jalan karena menggunakan smartphone yang melanggar Pasal 106 atau tilang.
\end{abstract}

\section{Pendahuluan}

Perkembangan zaman yang semakin canggih setiap harinya menjadi salah satu faktor terbesar yang mendorong kemajuan di bidang teknologi, informasi, komunikasi, sosial dan juga transportasi. Dalam perkembangan teknologi yang sangat pesat ini, maka diperlukan kebijaksanaan dalam menggunakan teknologi tersebut. Perkembangan teknologi yang dapat dilihat sangat berkembang pesat saat ini adalah smartphone. Smartphone merupakan salah satu perkembangan teknologi yang harus disikapi dengan bijak, karena smartphone kini dapat masuk kedalam setiap kehidupan manusia seperti penggunaan Global Positioning System (GPS) saat mengemudi, melakukan jual beli perdagangan melalui smartphone (online) dan sebagainya. Salah satu dampak dari smartphone ini dapat dirasakan dalam bidang transportasi. Saat ini, bahkan transportasi membutuhkan smartphone khususnya untuk pemakaian GPS atau digunakan oleh transportasi online dimana saat ini transportasi online sangat diminati oleh masyarakat. Penggunaan smartphone sebagai alat untuk membantu menunjuk jalan dengan adanya GPS, ternyata masih menimbulkan banyak permasalahan 
karena dikhawatirkan hal tersebut akan menyebabkan pengemudi kehilangan konsentrasi sehingga dapat menyebabkan terjadinya kecelakaan. Kecelakaan sendiri biasanya terjadi karena ketidakpatuhan pengguna jalan terhadap peraturan lalu lintas. Biasanya kecelakaan lalu lintas dalam sebagian kasus disebabkan karena perilaku manusia, dimana manusia tersebut melakukan perbuatan yang menyeleweng dari peraturan-peraturan yang telah dibuat. ${ }^{1}$

Di Indonesia sendiri data mengenai kecelakaan lalu lintas yang disebabkan oleh penggunaan smartphone ini belum banyak ditemukan sebab dalam pembuktian bahwa suatu kecelakaan tersebut disebabkan oleh penggunaan smartphone saat mengemudi agaklah sulit karena sebagian besar dari para korban atau pelakunya tidak mau mengaku. ${ }^{2}$ Penggunaan smartphone saat mengemudi ini bukan merupakan sesuatu yang dapat diabaikan begitu saja karena jika terus diabaikan maka kasuskasus yang telah disebutkan diatas dapat bertambah seiring berjalannya waktu, sehingga diperlukan upaya tegas yang dilakukan oleh penegak hukum untuk menertibkan dan memberi sanksi tegas pada pengemudi yang menggunakan ponsel saat mengemudikan kendaraan bermotor. Berdasarkan uraian latar belakang tersebut diatas, maka peneliti tertarik untuk melakukan penelitian dengan judul "Pertanggungjawaban Pidana Kecelakaan Lalu Lintas Karena Penggunaan Smartphone Saat Mengemudi".

\section{Rumusan Masalah}

1. Bagaimana bentuk tindak pidana kecelakaan lalu lintas yang disebabkan karena penggunaan smartphone saat mengemudi?

2. Bagaimana ketentuan perundang-undangan yang mengatur mengenai pertanggungjawaban pidana terhadap pengemudi yang menggunakan smartphone saat mengemudi dan menyebabkan kecelakaan?

\section{Metode Penelitian}

1. Jenis Penelitian

Jenis penelitian yang akan digunakan oleh penulis adalah penelitian normatif atau kepustakaan. Penelitian normatif ini adalah penelitian yang mencakup penelitian terhadap asas-asas hukum, sistematika hukum, taraf sinkronisasi hukum, sejarah hukum, dan perbandingan hukum. ${ }^{3}$ Jenis penelitian ini nantinya akan menghasilkan sebuah argumentasi hukum sebagai dasar penentu apakah suatu peristiwa sudah benar atau salah, serta bagaimana sebaiknya peristiwa itu menurut hukum. ${ }^{4}$

2. Teknik Pengumpulan Bahan Penelitian

Teknik pengumpulan data yang digunakan penulis di dalam penelitian normatif ini adalah:

a. Studi Pustaka

Teknik pengumpulan bahan hukum yang digunakan dalam penelitian yang digunakan oleh penulis didapat melalui studi pustaka. Penelusuran bahan hukum dilakukan dengan cara membaca buku dan dokumen cetak maupun penelusuran bahan hukum dari media elektronik.

b. Wawancara

1 Soerjono Soekanto, Polisi dan Lalu Lintas Analisis Menurut Sosiologi Hukum, Bandung, Mandar Maju, 1990, hlm. 45 .

2 Kumparan, "70 Ribu Kecelakaan dalam Setahun Gara-Gara Ponsel", Diakses dari https://kumparan.com/@kumparanoto/70-ribu-kecelakaan-dalam-setahun-gara-gara-ponsel, Pada Tanggal 4 November 2018 Pukul 18.55 WIB.

3 Sri Warjiyati, Memahami Dasar Ilmu Hukum: Konsep Dasar Ilmu Hukum, Jakarta, Prenadamedia, 2018, hlm. 10

4 Mukti Fajar ND dan Yulianto Achmad, Dualisme Penelitian Hukum Normatif dan Empiris, Yogyakarta, Pustaka Pelajar, 2010, hlm. 36. 
Wawancara dilakukan oleh penulis untuk mendapatkan pendapat terkait permasalahan yang diteliti oleh penulis guna dianalisis sebagai bahan hukum yang disertakan guna menjawab rumusan masalah.

3. Alat Pengumpul Data

a. Kepustakaan

Penulis dalam hal ini akan menggunakan komputer dalam membantu penulis mencari jawaban serta informasi atas permasalahan yang sedang diteliti oleh penulis.

b. Wawancara

Penulis dalam hal ini akan membuat daftar pertanyaan untuk narasumber yang akan memberikan informasi serta pendapat hukumnya mengenai permasalahan yang sedang diteliti, yaitu ahli pidana yang merupakan dosen fakultas hukum Universitas Islam Indonesia.

\section{Teknik Pengolahan Data}

Bahan hukum dan bahan non hukum yang didapatkan didalam proses penelitian ini yaitu informasi dari Kepolisian Daerah Istimewa Yogyakarta khususnya Kepolisian Resort Sleman dan Direktorat Lalu Lintas Kepolisian Daerah Istemewa Yogyakarta serta wawancara dengan seorang ahli pidana. Selanjutnya, penulis melakukan tahap editing dengan maksud agar data serta informasi yang dibutuhkan menjadi lebih lengkap, melalui pengkajian menggunakan asasasas hukum serta ajaran-ajaran dan pendapat para ahli yang dirangkai secara sistematis untuk mengkaji mengenai pertanggungjawaban pidana terhadap pengemudi yang menggunakan smartphone dan menyebabkan kecelakaan.

5. Teknik Analisis Data

Teknis analisis data yang digunakan dalam penelitian hukum normatif ini adalah deskriptif-kualitatif. Deskriptif maksudnya adalah bahwa dalam melakukan analisis terhadap bahan hukum, penulis berkeinginan untuk memberikan gambaran atau pemaparan atas subyek dan obyek penelitian sebagaimana hasil penelitian yang dilakukan. Analisis dengan pendekatan kualitatif akan menghasilkan data deskriptif analitis. Melalui analisis dengan pendekatan kualitatif ini maka penulis akan menentukan bahan hukum mana yang memiliki kualitas sebagai bahan hukum yang diperlukan.

\section{Hasil Penelitian dan Analisis}

\section{Bentuk Tindak Pidana Kecelakaan Lalu Lintas Karena Penggunaan Smartphone Saat Mengemudi}

Tindak pidana adalah kelakuan manusia yang dirumuskan dalam undang-undang dan bersifat melawan hukum, yang patut dipidana dan dilakukan dengan adanya kesalahan. ${ }^{5}$ Orang yang melakukan perbuatan pidana akan mempertanggungjawabkan perbuatan dengan pidana apabila ia mempunyai kesalahan, seseorang mempunyai kesalahan apabila pada waktu melakukan perbuatan dilihat dari segi masyarakat menunjukan pandangan normatif mengenai kesalahan yang dilakukan. ${ }^{6}$ Didalam berlalu lintas seseorang juga dapat dianggap melakukan tindak pidana apabila orang tersebut yang karena kesalahannya menyebabkan kecelakaan baik kecelakaan yang menyebabkan luka-luka hingga yang menyebabkan kematian. Andi Zainal Abidin Farid membagi unsur-unsur tindak pidana sebagai berikut: ${ }^{7}$

a. "Unsur Actus Reus (Delictum)/unsur objektif: Unsur Perbuatan pidana

1) Unsur-unsur konstitutif sesuai uraian delik.

2) Unsur diam-diam.

5 Andi Hamzah, Bunga Rampai Hukum Pidana dan Acara Pidana, Jakarta, Ghalia Indonesia, 2001, hlm. 22

6 Ibid.

7 A. Zainal Abidin Farid, Hukum Pidana I, Cetakan Pertama, Jakarta, Sinar Grafika, 1995, hlm. 235. 
a) Perbuatan aktif atau pasif.

b) Melawan hukum obyektif atau subyektif.

c) Tidak ada dasar pembenar.

b. Unsur Mens Rea/unsur subjektif: Unsur pertanggungjawaban pidana.

1) Kemampuan bertanggungjawab.

2) Kesalahan dalam arti luas.

a) Dolus (kesengajaan):

(1) Sengaja sebagai niat.

(2) Sengaja sadar akan kepastian atau keharusan.

(3) Sengaja sadar akan kemungkinan.

b) Culpa lata:

(1) Culpa lata yang disadari (alpa).

(2) Culpa lata yang tidak disadari (lalai).

Menurut Dr. Muzakkir, S.H., M.H. seorang ahli pidana yang menjadi dosen di salah satu universitas swasta di Yogyakarta mengatakan bahwa: ${ }^{8}$

"Tidak semua kecelakaan lalu lintas yang terjadi adalah karena suatu kealpaan, karena bisa jadi kecelakaan lalu lintas disebabkan karena perbuatan sengaja pengendara yang melakukan perbuatan dimana perbuatan tersebut telah dilarang dan hasil dari perbuatan tersebut menyebabkan kecelakaan lalu lintas."

Berdasarkan penjelasan di bab sebelumnya bahwa secara garis besar kecelakaankecelakaan lalu lintas cenderung disebabkan oleh 4 faktor yang saling berkaitan, yakni faktorfaktor manusia, kendaraan, jalan raya, dan lingkungan. Dari penelitian-penelitian yang telah dilakukan, maka dari keempat faktor tersebut, faktor manusia sebagai pemakai jalan raya yang memegang peranan sangat penting. Kekurangan-kekurangan yang ada pada manusia pemakai jalan raya, merupakan penyebab utama terjadinya kecelakaan lalu lintas. Kekurangankekurangan tersebut, adalah antara lain: ${ }^{9}$

a. Konsentrasi, perkiraan dan ketrampilan yang kurang baik.

b. Reaksi yang hebat.

c. Kelainan-kelainan fisik.

d. Gangguan emosional.

e. Kelelahan fisik dan kepribadian.

f. Kurangnya disiplin atau ketaatan.

Smartphone menjadi salah satu hal yang memiliki kemungkinan terbesar yang menyebabkan terjadinya kecelakaan lalu lintas. Akan tetapi, masih banyak perdebatan yang terjadi mengenai bentuk tindak pidana yang diberikan kepada pelaku kecelakaan yang disebabkan karena menggunakan smartphone saat mengemudi ini, sehingga pengemudi tersebut juga dapat dikenakan pertanggungjawaban pidananya apabila memenuhi unsur-unsur dapat dipidananya seseorang yakni: ${ }^{10}$

a. Kemampuan bertanggungjawab atau dapat dipertanggungjawabkan dari si pembuat.

b. Adanya perbuatan melawan hukum yaitu suatu sikap psikis pelaku yang terkait dengan kelakuannya yaitu disengaja dan kurang hati-hati atau karena kelalaiannya.

c. Tidak adanya alasan pembenar atau alasan yang menghapuskan pertanggungjawaban pidana bagi si pembuat.

Secara spesifik didalam Undang-Undang Nomor 22 Tahun 2009 Tentang Lalu Lintas dan Angkutan Jalan tidak menyebutkan definisi secara jelas mengenai pengemudi yang menggunakan smartphone saat mengemudi dan sanksi pidana apabila karena hal tersebut terjadi kecelakaan, hanya saja disebutkan didalam undang-undang tersebut jika karena kelalaiannya atau kesengajaannya dalam berkendara mengakibatkan kecelakaan lalu lintas

\footnotetext{
8 Dr. Muzakkir, S.H., M.H. Dosen Pidana Universitas Islam Indonesia dalam wawancara di Kampus UII, 20 Mei 2019.

${ }^{9}$ Penelitian di Polres Sleman

10 Moeljatno, Op. Cit, hlm 50.
} 
maka hal tersebut melanggar Pasal 310 dan/atau Pasal 311 Undang-Undang Nomor 22 Tahun 2009 Tentang Lalu Lintas dan Angkutan Jalan Selain itu hanya dikatakan didalam UndangUndang Nomor 22 Tahun 2009 Tentang Lalu Lintas dan Angkutan Jalan mengenai berkendara dengan penuh konsentrasi. Penggunaan smartphone saat mengemudi ini dinilai sangat mempengaruhi konsentrasi pengendara saat mengemudi, seperti yang dikatakan oleh Dr. Muzzakir, S.H., M.H. bahwa:

"Kewajiban pengendara adalah mengemudi dengan wajar dan penuh konsentrasi, apabila pengendara menggunakan smartphone dimana hal tersebut jelas mengganggu konsentrasi." 11 Hal tersebut dikatakan mengganggu konsentrasi dikarenakan ketika menggunakan smartphone seseorang akan melihat serta memegang sehingga konsentrasi untuk melihat ke arah jalanan akan terpecah dan dapat menyebabkan kemungkinan untuk terjadi kecelakaan."

Seperti yang telah diatur didalam Undang-Undang Nomor 22 Tahun 2009 Tentang Lalu Lintas dan Angkutan Jalan Pasal 106 ayat (1) yang berbunyi:

"Setiap orang yang mengemudikan Kendaraan Bermotor di Jalan wajib mengemudikan kendaraannya dengan wajar dan penuh konsentrasi." Berdasarkan pasal 106 ayat (1) tersebut, tentu saja menggunakan smartphone baik yang digunakan untuk berkomunikasi seperti mengirim pesan, menelepon atau menggunakan GPS termasuk kedalam hal yang akan mengganggu konsentrasi pengendara. Berdasarkan kutipan wawancara terhadap Irjen Pol. Royke Lumowa kepada wartawan di Bekasi Jawa Barat bahwasanya mendengarkan radio dan GPS diperbolehkan asalkan tidak sampai melanggar aturan Pasal 106 UU LLAJ seperti menonton TV, video, lelah, mengantuk, mabuk, dan menggunakan smartphone. ${ }^{12}$

Berdasarkan penjelasan mengenai penggunaan smartphone saat mengemudi yang dapat menyebabkan kecelakaan lalu lintas ini karena kurangnya konsentrasi dan dilakukan secara sadar oleh pengemudi sehingga dapat dikatakan bahwa perbuatan menggunakan smartphone ini menjadi bentuk tindak pidana kesengajaan dan bukan karena kealpaannya. Menurut apa yang disampaikan oleh Dr. Muzakkir, S.H., M.H. bahwa:

"Pengemudi yang menggunakan smartphone saat mengemudi itu ya sudah secara sadar mengetahui bahwa konsentrasi dalam mengemudikan kendaraan akan terpecah, sehingga apabila terjadi kecelakaan tentu perbuatan pengemudi tersebut akan dinilai sebagai suatu kesengajaan meskipun pengemudi tidak menginginkan kecelakaan itu terjadi."13

Teori kesengajaan didalam hukum pidana di Indonesia menyebutkan bahwa kesengajaan terdiri dari tiga macam, yaitu sebagai berikut: ${ }^{14}$

a. Kesengajaan yang bersifat tujuan.

Bahwa dengan kesengajaan yang bersifat tujuan, si pelaku dapat dipertanggungjawabkan dan mudah dapat dimengerti oleh khalayak ramai. Apabila kesengajaan seperti ini ada pada suatu tindak pidana, si pelaku pantas dikenakan hukuman pidana. Karena dengan adanya kesengajaan yang bersifat tujuan ini, berarti si pelaku benar-benar menghendaki mencapai suatu akibat yang menjadi pokok alasan diadakannya ancaman hukuman ini.

b. Kesengajaan secara sadar kepastian.

Kesengajaan ini ada apabila si pelaku, dengan perbuatannya tidak bertujuan untuk mencapai akibat yang menjadi dasar dari delik, tetapi ia tahu benar bahwa akibat itu pasti akan mengikuti perbuatan itu.

c. Kesengajaan secara sadar kemungkinan.

11 Dr. Muzakkir, S.H., M.H. Dosen Pidana Universitas Islam Indonesia dalam wawancara di Kampus UII, 20 Mei 2019.

12 Ruly Kurniawan, 2019, Menggunakan GPS Boleh, Asal, diakses dari https://oto.detik.com/berita/3899147/gunakan-gps-di-jalan-boleh-asal Pada 30 Mei 2019 Pukul 10.30 WIB.

13 Dr. Muzakkir, S.H., M.H. Dosen Pidana Universitas Islam Indonesia dalam wawancara di Kampus UII, 20 Mei 2019.

14 Barda Nawawi Arief. Op. Cit. Hlm. 49. 
Kesengajaan ini yang terang-terang tidak disertai bayangan suatu kepastian akan terjadi akibat yang bersangkutan, melainkan hanya dibayangkan suatu kemungkinan belaka akan akibat itu. Selanjutnya mengenai kealpaan karena merupakan bentuk dari kesalahan yang menghasilkan dapat dimintai pertanggungjawaban atas perbuatan seseorang yang dilakukannya.

Berdasarkan teori kesengajaan tersebut, pengemudi yang menggunakan smartphone saat mengemudi dan terjadi kecelakaan dapat masuk kedalam bentuk tindak pidana kesengajaan sebagai kesadaran kemungkinan. Meskipun pengertian dari kesengajaan dengan kemungkinan dan pengertian dari kealpaan (culpa) sedikit sama, akan tetapi menurut Van dijk, perbedaan antara kealpaan dengan kesengajaan dan keinsafan (sadar) kemungkinan (dolus eventualis) dapat diketahui dengan contoh sebagai berikut: 15

"Pekerja yang sedang bekerja diatas rumah kemudian melemparkan sebuah balok kebawah dan menimpa orang. Jika disekeliling rumah biasanya ada orang yang lewat, kemudian balok tersebut dilempar tanpa memikirkan kemungkinan besar akan ada orang yang berjalan dibawahnya, maka dapat dikatakan pekerja tersebut telah melakukan suatu kealpaan. Sedangkan, apabila mereka mengingat bahwa ada kemungkinan bisa terbunuhnya seseorang yang sedang susah payah, maka hal itu dinamakan kesengajaan dengan keinsafan kemungkinan (dolus eventualis)."

Namun, karena perbedaan antara kesengajaan dengan sadar kemungkinan dan kealpaan sangatlah berbeda tipis, oleh karena itu kealpaan juga dapat masuk menjadi salah satu pilihan bentuk tindak pidana yang dapat diberikan pada kasus penggunaan smartphone saat mengemudi ini.

Contoh penerapan kesengajaan dengan sadar kemungkinan ini yang dikaitkan dengan penggunaan smartphone saat mengemudi dan terjadi kecelakaan lalu lintas adalah apabila pengemudi dengan sadar saat menggunakan smartphone tersebut akan menghilangkan konsentrasi dan dapat mengingat bahwa kemungkinan terbunuhnya pengguna jalan lain jika terjadi kecelakaan maka pengemudi tersebut dapat dikatakan masuk kedalam unsur kesengajaan dengan sadar kemungkinan.

Apabila dilihat dari teori kealpaan yang telah dijelaskan pada bab sebelumnya yaitu kealpaan yang dilihat dari sudut pandang pelaku yang melakukan perbuatan tersebut hingga terjadi kecelakaan maka terdapat pilihan lain seperti teori kealpaan berupa: 16

1. Kealpaan yang disadari (bewuste schuld).

2. Kealpaan yang tidak disadari (onbewuste schuld).

Ketika seorang pengemudi yang menggunakan smartphone bisa dengan sengaja menggunakan smartphone saat mengemudi namun pengendara tersebut tidak memperkirakan apa yang akan terjadi seperti kecelakaan atau pengemudi memperkirakan hal tersebut namun karena kekurang hati-hatiannya maka kecelakaan terjadi. Contoh kealpaan ini penulis dapat dari pengalaman pribadi seorang narasumber. Narasumber tersebut sedang mengendarai kendaraan bermotor roda empat dan sedang berhenti tepat di belakang truk, kemudian narasumber tersebut menggunakan smartphone karena terdapat pesan yang masuk dan secara otomatis narasumber tersebut membalas pesan tersebut dan karena kelalaiannya narasumber tersebut melepaskan pijakan rem mobil sehingga mobil tersebut berjalan dan menabrak bagian belakang truk yang ada tepat di depan mobil narasumber. Sehingga perbuatan yang dilakukan oleh narasumber tersebut dapat dikatakan masuk dalam bentuk kealpaan karena kekurang hati-hatiannya menyebabkan kerusakan kendaraan/barang.

\footnotetext{
15 Muhammad Ramadan Kiro, Penerapan Unsur Delik Kesengajaan Pada Kecelakaan Lalu Lintas yang mengakibatkan hilangnya nyawa orang lain yang dilakukan oleh orang karena pengaruh alkohol, Jurnal Paper Academia Edu, Universitas Hasanuddin, 2015, hlm. 11.

16 Andi Sofyan dan Nur Aziza, Buku Ajar Hukum Pidana, Makassar, Pustaka Pena Press, 2016. hlm. 124.
} 


\section{Pertanggungjawaban Pidana Terhadap Pengemudi Kendaraan Bermotor yang} Menggunakan Smartphone Saat Mengemudi dan Menyebabkan Kecelakaan Lalu Lintas

Pertanggungjawaban pidana adalah pertanggungjawaban orang terhadap tindak pidana yang telah dilakukannya, maksudnya adalah hal yang dipertanggungjawabkan oleh orang tersebut adalah tindak pidana yang telah dilakukannya dan telah menimbulkan akibat. Sehingga, terjadinya pertanggungjawaban pidana ini karena telah ada tindak pidana yang dilakukan oleh seseorang sebelumnya. ${ }^{17}$

Secara normatif peraturan mengenai apa yang boleh dilakukan dan apa saja yang dilarang serta sanksi pidana yang dapat diberikan apabila larangan tersebut dilanggar saat sedang berlalu lintas di Indonesia sendiri dipayungi oleh UU LLAJ. Setiap hari, manusia dalam melakukan kegiatan sehari-harinya menggunakan jalan raya, setiap manusia yang menggunakan jalan raya menginginkan kenyamanan, keamanan dan ketertiban dalam berlalu lintas, akan tetapi nyatanya seperti data yang telah berikan oleh Kepolisian Republik Indonesia yang dikutip oleh Kementerian Kesehatan Republik Indonesia (Ministry Of Health Republic of Indonesia) bahwasannya di Indonesia rata-rata 3 orang meninggal setiap jam akibat kecelakaan di jalan raya. Data tersebut juga menyatakan bahwa besarnya jumlah kecelakaan tersebut disebabkan oleh beberapa faktor, yaitu: ${ }^{18}$
a. Faktor Manusia sebanyak $61 \%$.
b. Faktor Kendaraan sebanyak $9 \%$.
c. Faktor prasarana dan lingkungan $30 \%$.

Tidak hanya data dari Kepolisian Republik Indonesia, bahkan World Health Organization (WHO) juga menyatakan bahwa pada Tahun 2016 - 2019 Indonesia menjadi salah satu negara yang memiliki tingkat kecelakaan tertinggi yang mengakibatkan luka ringan, luka berat, hingga kematian di dunia dengan persentase $12-20 \% .^{19}$

Isu mengenai sanksi yang akan diberikan kepada pengemudi yang menggunakan smartphone saat mengemudi seperti berkomunikasi dan penggunaan GPS yang berlebihan hingga menyebabkan terpecahnya konsentrasi serta menimbulkan kecelakaan lalu lintas sebenarnya sudah lama menjadi perdebatan, bahkan sempat diajukan untuk diuji materi ke Mahkamah Kontitusi mengenai Pasal 106 Undang-Undang Nomor 22 Tahun 2009 Tentang Lalu Lintas dan Angkutan Jalan akan tetapi Mahkamah Konstitusi menolak permohonan tersebut karena permohonan yang diajukan oleh pemohon tidak beralasan menurut hukum, dan menyatakan bahwa menggunakan smartphone untuk GPS atau berkomunikasi akan tetap diberikan sanksi pidana. ${ }^{20}$

Di Indonesia sendiri aturan pelaksana mengenai sanksi yang akan diberikan kepada pengendara yang menggunakan smartphone saat mengemudi dan menyebabkan kecelakaan masih tidak jelas karena hal yang ditegaskan oleh Mahkamah Konstitusi hanya mengenai pelanggarannya saja yaitu menggunakan smartphone. ${ }^{21}$ Hal ini diketahui berdasarkan penelitian yang dilakukan di Direktorat Lalu Lintas Polda DIY, bahwa pihak kepolisian saat ini belum menerima perintah khusus dimana dapat melakukan tindakan tegas kepada pengemudi yang menggunakan smartphone saat mengemudi. ${ }^{22}$

Sehingga sanksi yang dapat diberikan terhadap pengemudi yang menggunakan smartphone jika ditinjau dari Pasal 106 ayat (1) Undang-Undang Nomor 22 Tahun 2009

17 Ibid, hlm. 123

18 Kementerian

Kesehatan

Republik

Indonesia,

Diakses

dari

http://www.depkes.go.id/article/view/17082100002/rata-rata-3-tiga-orang-meninggal-setiap-jam-akibatkecelakaan-jalan.html, Pada Tanggal 10 Mei 2019 Pukul 13.00 WIB.

19 World Health Organization, diakses dari http://apps.who.int/gho/data/node.main.A997?lang=en, pada Tanggal 10 Mei 2019 Pada Pukul 13.25 WIB.

20 Putusan Mahkamah Konstitusi, Putusan Nomor 23/PUU-XVI/2018 yang Diterbitkan Pada 30 Januari 2019.

21 Ruly Kurniawan, Loc. Cit.

22 Penelitian yang dilakukan di Ditlantas Polda DIY pada 20 Maret 2019. 
Tentang Lalu Lintas dan Angkutan Jalan maka sanksi yang akan diberikan tertuang didalam Pasal 283 Undang-Undang Nomor 22 Tahun 2009 Tentang Lalu Lintas dan Angkutan Jalan yang berbunyi:

"Setiap orang yang mengemudikan Kendaraan Bermotor di Jalan secara tidak wajar dan melakukan kegiatan lain atau dipengaruhi oleh suatu keadaan yang mengakibatkan gangguan konsentrasi dalam mengemudi di Jalan sebagaimana dimaksud dalam Pasal 106 ayat (1) dipidana dengan pidana kurungan paling lama 3 (tiga) bulan atau denda paling banyak Rp750.000,00 (tujuh ratus lima puluh ribu rupiah)." Pasal tersebut dapat dikenakan sebagai sanksi atas pelanggaran pengendara yang menggunakan smartphone saat mengemudi.

Akan tetapi apabila karena penggunaan smartphone itu mengakibatkan kecelakaan lalu lintas maka sanksi yang diberikan dapat berbeda. Oleh karena itu, apabila terjadi kasus dimana terdapat suatu kecelakaan yang disebabkan karena pengemudi memainkan smartphone maka dapat dikatakan bahwa kasus ini menjadi lebih berat daripada kecelakaan karena kealpaan yang tidak disadari oleh pengemudi. Contoh lainnya yang dapat dikategorikan sama berat seperti dengan penggunaan smartphone yakni adalah pengemudi yang mengemudi dalam keadaan terpengaruh oleh minuman beralkohol, obat-obatan terlarang, mengantuk dan sebagainya. Sehingga dapat dikatakan bahwa apabila karena penggunaan smartphone merupakan penyebab terjadinya kecelakaan maka hal tersebut akan memenuhi unsur kesengajaan dengan kemungkinan. Menurut Dr. Muzakkir, S.H., M.H. mengatakan bahwa:

"Penggunaan smartphone saat mengemudi dan terjadi kecelakaan lalu lintas karenanya akan masuk kedalam kategori kesengajaan dengan kemungkinan, dimana pengendara tersebut tidak menghendaki terjadinya kecelakaan tersebut namun karena kesalahannya yakni dengan sengaja menggunakan smartphone hingga terjadi kecelakaan itulah yang dimaksud dengan kesengajaan dengan kemungkinan." Dr. Muzakkir juga menambahkan bahwa, "Unsur kesengajaan dengan kemungkinan akan diberikan sanksi pidana apabila akibat dari larangan yang dilanggar tersebut terjadi, akan tetapi apabila akibat tersebut tidak timbul maka tidak dapat dikenakan sanksi kesengajaan karena perbuatan tersebut hanya sekedar kemungkinan yang akan terjadi." 23

Secara umum mengenai kewajiban dan tanggung jawab pengemudi, pemilik kendaraan bermotor, dan/atau perusahaan angkutan diatur dalam Pasal 234 ayat (1) Undang-Undang Nomor 22 Tahun 2009 Tentang Lalu Lintas dan Angkutan Jalan, yang menyatakan bahwa: "Pengemudi, pemilik kendaraan bermotor, dan/atau perusahaan angkutan umum bertanggung jawab atas kerugian yang diderita oleh penumpang dan/atau pemilik barang dan/atau pihak ketiga karena kelalaian pengemudi". Namun, ketentuan tersebut tidak berlaku jika:

a. Adanya keadaan memaksa yang tidak dapat dibiarkan atau di luar kemampuan pengemudi;

b. Disebabkan oleh perilaku korban sendiri atau pihak ketiga; dan/atau

c. Disebabkan gerakan orang dan/atau hewan walaupun telah diambil tindakan pencegahan.

Pihak yang menyebabkan terjadinya kecelakaan lalu lintas wajib mengganti kerugian yang besarannya ditentukan berdasarkan putusan pengadilan. Kewajiban mengganti kerugian ini dapat dilakukan di luar pengadilan jika terjadi kesepakatan damai di antara para pihak yang terlibat. Jadi, dapat disimpulkan bahwa bentuk pertanggung-jawaban atas kecelakaan lalu lintas yang hanya mengakibatkan kerugian materi tanpa korban jiwa adalah dalam bentuk penggantian kerugian. ${ }^{24}$

Seperti yang dikatakan oleh Dr. Muzakkir, S.H., M.H. mengenai alasan penggunaan smartphone saat mengemudi hingga terjadi kecelakaan ini dapat disebut sebagai kesengajaan dengan sadar kemungkinan adalah bahwa apabila kecelakaan yang disebabkan oleh smartphone ini benar-benar terjadi hingga menyebabkan orang lain terluka atau meninggal maka pengemudi dapat dipidana dengan pasal kesengajaan yang ada didalam Undang-Undang Nomor 22 Tahun 2009 Tentang Lalu Lintas dan Angkutan Jalan, namun jika kecelakaan tidak timbul maka hal itu disebut sebagai sebuah kemungkinan saja sehingga apabila pengemudi

23 Dr. Muzakkir, S.H., M.H. Dosen Pidana Universitas Islam Indonesia dalam wawancara di Kampus UII, 20 Mei 2019.

24 M. Budi Hendrawan dkk. Op. Cit. Hl m. 63. 
terdapati menggunakan smartphone saat mengemudi oleh kepolisian maka pengendara dapat dikenakan sanksi pelanggaran yang ada didalam Pasal 283 Undang-Undang Nomor 22 Tahun 2009 Tentang Lalu Lintas dan Angkutan Jalan. ${ }^{25}$

Pasal 106 juga dapat menjadi dasar untuk pengemudi dikenakan tilang apabila mengemudi sambil menggunakan smartphone karena dianggap dapat mengganggu konsentrasi saat mengemudi. Tilang tersebut tidak hanya mencakup mengenai pengemudi yang ketahuan tidak menggunakan seat belt, menerobos lampu lalu lintas atau mengenai batas kecepatan pengemudi dalam berkendara, akan tetapi saat ini penggunaan smartphone saat mengemudi juga akan dikenakan tilang.

Apabila kecelakaan karena pengemudi yang menggunakan smartphone ini menyebabkan seseorang terluka atau meninggal dunia maka sesuai dengan apa yang dibahas pada poin A memiliki dua pilihan yakni dapat dilihat sebagai tindak pidana kesengajaan dengan sadar kemungkinan atau sebagai bentuk kealpaan karena kurangnya kehati-hatian. Pasal mengenai kealpaan dan kesengajaan dalam didalam Undang-Undang Nomor 22 Tahun 2009 Tentang Lalu Lintas dan Angkutan Jalan tercantum didalam Pasal 310 dan 311 yang berbunyi:

Pasal 310 Undang-Undang Nomor 22 Tahun 2009 Tentang Lalu Lintas dan Angkutan Jalan:

(1) Setiap orang yang mengemudikan Kendaraan Bermotor yang karena kelalaiannya mengakibatkan Kecelakaan Lalu Lintas dengan kerusakan Kendaraan dan/atau barang sebagaimana dimaksud dalam Pasal 229 ayat (2), dipidana dengan pidana penjara paling lama 6 (enam) bulan dan/ atau denda paling banyak Rp 1.000.000,00 (satu juta rupiah).

(2) Setiap orang yang mengemudikan Kendaraan Bermotor yang karena kelalaiannya mengakibatkan Kecelakaan Lalu Lintas dengan korban luka ringan dan kerusakan Kendaraan dan/atau barang sebagaimana dimaksud dalam Pasal 229 ayat (3), dipidana dengan pidana penjara paling lama 1 (satu) tahun dan/atau denda paling banyak Rp2.000.000,00 (dua juta rupiah).

(3) Setiap orang yang mengemudikan Kendaraan Bermotor yang karena kelalaiannya mengakibatkan Kecelakaan Lalu Lintas dengan korban luka berat sebagaimana dimaksud dalam Pasal 229 ayat (4), dipidana dengan pidana penjara paling lama 5 (lima) tahun dan/atau denda paling banyak Rp10.000.000,00 (sepuluh juta rupiah).

(4) Dalam hal kecelakaan sebagaimana dimaksud pada ayat (3) yang mengakibatkan orang lain meninggal dunia, dipidana dengan pidana penjara paling lama 6 (enam) tahun dan/atau denda paling banyak Rp12.000.000,00 (dua belas juta rupiah).

Pasal 311 Undang-Undang Nomor 22 Tahun 2009 Tentang Lalu Lintas dan Angkutan Jalan:

(1) Setiap orang yang dengan sengaja mengemudikan Kendaraan Bermotor dengan cara atau keadaan yang membahayakan bagi nyawa atau barang dipidana dengan pidana penjara paling lama 1 (satu) tahun atau denda paling banyak Rp3.000.000,00 (tiga juta rupiah).

(2) Dalam hal perbuatan sebagaimana dimaksud pada ayat (1) mengakibatkan Kecelakaan Lalu Lintas dengan kerusakan Kendaraan dan/ atau barang sebagaimana dimaksud dalam Pasal 229 ayat (2), pelaku dipidana dengan pidana penjara paling lama 2 (dua) tahun atau denda paling banyak Rp4.000.000,00 (empat juta rupiah).

(3) Dalam hal perbuatan sebagaimana dimaksud pada ayat (1) mengakibatkan Kecelakaan Lalu Lintas dengan korban luka ringan dan kerusakan Kendaraan dan/atau barang sebagaimana dimaksud dalam Pasal 229 ayat (3), pelaku dipidana dengan pidana penjara paling lama 4 (empat) tahun atau denda paling banyak Rp8.000.000,00 (delapan juta rupiah).

(4) Dalam hal perbuatan sebagaimana dimaksud pada ayat (1) mengakibatkan Kecelakaan Lalu Lintas dengan korban luka berat sebagaimana dimaksud dalam Pasal 229 ayat (4),

25 Dr. Muzakkir, S.H., M.H. Dosen Pidana Universitas Islam Indonesia dalam wawancara di Kampus UII, 20 Mei 2019. 
pelaku dipidana dengan pidana penjara paling lama 10 (sepuluh) tahun atau denda paling banyak Rp20.000.000,00 (dua puluh juta rupiah).

(5) Dalam hal perbuatan sebagaimana dimaksud pada ayat (4) mengakibatkan orang lain meninggal dunia, pelaku dipidana dengan pidana penjara paling lama 12 (dua belas) tahun atau denda paling banyak Rp24.000.000,00 (dua puluh empat juta rupiah).

Sehingga dapat diketahui bahwa tindak pidana yang dapat diberikan kepada pengemudi yang menggunakan smartphone saat mengemudi dan menyebabkan kecelakaan ini dapat dikenakan dua teori tindak pidana yakni kesengajaan dengan sadar kemungkinan atau kealpaan itu sendiri.

\section{Simpulan dan Saran}

\section{Simpulan}

Berdasarkan hasil penelitian serta analisis tentang Pertanggungjawaban Pidana Kecelakaan Lalu Lintas Karena Penggunaan Smartphone Saat Mengemudi yang telah dilakukan dan dikemukakan pada pembahasan sebelumnya, maka penulis dapat mengambil kesimpulan sebagai berikut :

a. Tindak pidana mengandung beberapa unsur yaitu adanya unsur subyektif seperti kemampuan bertanggungjawab, unsur kesalahan (schuld) yang terdiri dari kealpaan dan kesengajaan serta unsur obyektif seperti perbuatan manusia, akibat dari perbuatan manusia, keadaan-keadaan, dan sifat melawan hukum. Pengemudi yang menggunakan smartphone saat mengemudi dan menyebabkan kecelakaan dapat dikategorikan melakukan tindak pidana. Tindak pidana yang dilakukan pengemudi yang masuk dalam penelitian ini dapat dikategorikan sebagai tindak pidana yang masuk dalam 2 (dua) teori yang terdiri dari:

1) Kesengajaan secara sadar kemungkinan.

Kesengajaan ini yang terang-terang tidak disertai bayangan suatu kepastian akan terjadi akibat yang bersangkutan, melainkan hanya dibayangkan suatu kemungkinan belaka akan akibat itu. Selanjutnya mengenai kealpaan karena merupakan bentuk dari kesalahan yang menghasilkan dapat dimintai pertanggungjawaban atas perbuatan seseorang yang dilakukannya.

2) Kealpaan yang dilihat dari sudut pandang pelaku yakni:

a) Kealpaan yang disadari (bewuste schuld).

Kealpaan yang disadari terjadi apabila si pelaku tersebut dapat membayangkan atau memperkirakan kemungkinan yang dapat ditimbulkan dari perbuatan yang dilakukannya, meskipun pelaku juga telah berusaha untuk melakukan upaya pencegahan agar tidak terjadi akibat tersebut.

b) Kealpaan yang tidak disadari (onbewuste schuld).

Kealpaan yang tidak disadari merupakan kebalikan dari kealpaan yang disadari, maksudnya adalah suatu akibat yang terjadi apabila si pelaku tidak membayangkan atau tidak memperkirakan kemungkinan yang dapat ditimbulkan dari perbuatan yang dilakukannya.

Berdasarkan teori kesengajaan dan kealpaan tersebut, bentuk tindak pidana yang sesuai diberikan kepada pengemudi yang menggunakan smartphone saat mengemudi dan terjadi kecelakaan dapat masuk kedalam bentuk tindak pidana kesengajaan dengan sadar kemungkinan, karena dengan perbuatan yang dilanggar yakni menggunakan smartphone saat mengemudi apabila menyebabkan kecelakaan maka dikenakan sanksi pidana, sedangkan apabila tidak terjadi kecelakaan maka tidak dapat dikenakan sanksi pidana.

b. Pertanggungjawaban pidana kepada pengemudi yang menggunakan smartphone saat mengemudi dan menyebabkan kecelakaan dapat dijatuhi pertanggungjawaban. 
Pertanggungjawaban pidana tersebut harus memenuhi unsur dapat dipidananya seseorang seperti:

1) Melakukan perbuatan pidana.

2) Kemampuan bertanggungjawab.

3) Memiliki unsur kesalahan baik kesengajaan atau kealpaan.

4) Tidak ada alasan pemaaf dan alasan pembenar.

Apabila keempat unsur tersebut tidak ada dalam diri pengemudi yang menggunakan smartphone saat mengemudi maka pengemudi tersebut tidak dapat dimintai pertanggungjawaban pidananya terhadap kecelakaan lalu lintas yang menyebabkan luka atau meninggal dunia. Namun, apabila pengemudi yang menyebabkan kecelakaan karena menggunakan smartphone saat mengemudi ini telah memenuhi keempat unsur diatas, maka perbuatan tersebut dapat masuk kedalam kesengajaan dengan sadar kemungkinan atau juga kealpaan menurut Undang-Undang Nomor 22 Tahun 2009 Tentang Lalu Lintas dan Angkutan Jalan, dan hal tersebut dapat diberikan sanksi sesuai Pasal 310 untuk kealpaan dan Pasal 311 untuk kesengajaan. Namun untuk kesengajaan kemungkinan ini apabila tidak terjadi kecelakaan maka pengemudi tetap dapat diberikan sanksi pelanggaran terhadap Pasal 106 Undang-Undang Nomor 22 Tahun 2009 Tentang Lalu Lintas dan Angkutan Jalan karena menggunakan smartphone saat mengemudi yang dapat menghilangkan konsentrasi sehingga sanksi yang dapat dikenakan sesuai Pasal 283 Undang-Undang Nomor 22 Tahun 2009 Tentang Lalu Lintas dan Angkutan Jalan, pasal 106 tersebut juga dapat digunakan sebagai bentuk sanksi berupa tilang kepada para pengemudi.

\section{Saran}

a. Instansi penegak hukum di seluruh daerah di Indonesia seharusnya lebih aktif untuk melakukan sosialisasi mengenai sanksi pidana yang dapat diberikan ketika menggunakan smartphone saat mengemudi dan menyebabkan kecelakaan untuk lebih aktif melakukan kegiatan preventif

b. Instansi penegak hukum untuk lebih memberikan tindakan yang tegas apabila terdapat pengendara yang melanggar aturan seperti menggunakan smartphone saat mengemudi dengan cara yang dapat dilakukan oleh Pemerintah Indonesia yakni dapat meniru sebagian negara maju untuk meletakkan CCTV di jalan raya dengan tujuan mengetahui setiap pergerakan pengendara, karena tanpa bantuan CCTV akan sulit untuk ditemukannya penyebab kecelakaan karena penggunaan smartphone saat mengemudi. Serta pemerintah juga diharapkan agar supaya dapat membentuk aturan pelaksanaan mengenai larangan penggunaan smartphone saat mengemudi dan berlaku untuk setiap daerah di Indonesia.

\section{DAFTAR PUSTAKA}

\section{Buku}

Fajar ND, Mukti dan Yulianto Achmad, 2010, Dualisme Penelitian Hukum Normatif dan Empiris, Yogyakarta, Pustaka Pelajar.

Hamzah, Andi, 2001, Bunga Rampai Hukum Pidana dan Acara Pidana, Jakarta, Ghalia Indonesia. Moeljatno, 2008, Asas-Asas Hukum Pidana, Jakarta, Rineka Cipta.

Nawawi Arief, Barda, 2001, Masalah Penegakan Hukum dan Kebijakan Penanggulangan Kejahatan, Bandung, PT. Citra Aditya Bakti.

Sofyan, Andi dan Nur Aziza, 2016, Buku Ajar Hukum Pidana, Makassar, Pustaka Pena Press.

Soekanto, Soerjono, 1990, Polisi dan Lalu Lintas Analisis Menurut Sosiologi Hukum, Bandung, Mandar Maju. 
Sri Warjiyati, 2018, Memahami Dasar Ilmu Hukum: Konsep Dasar Ilmu Hukum, Jakarta: Prenadamedia

Zainal Abidin Farid, A, 1995, Hukum Pidana I, Cetakan Pertama, Jakarta, Sinar Grafika.

\section{Jurnal}

Agio V. Sangki. 2012. “Tanggung Jawab Pidana Pengemudi Kendaraan yang Mengakibatkan Kematian dalam Kecelakaan Lalu Lintas". Jurnal Lex Crimen Vol. I, No. 1.

Andi Zeinal Marala, "Penegakan Hukum Pidana Terhadap Kelalaian Pengemudi Yang Menimbulkan Kecelakaan Jalan Raya", Lex Crimen Vol. IV, No. 5.

Hendrawan, M. B., Syahrin, A., Ginting, B., \& Mulyadi, M. 2015, "Hubungan antara Kesengajaan terhadap Pertanggungjawaban Pidana dalam Kasus Kecelakaan Lalu Lintas di Jalan yang Menyebabkan Hilangnya Nyawa Orang Seseorang". USU Law Journal, Vol. III, No. 1.

Istri, Y.D.O.S.T dan Anisa N, 2013, "Tinjauan Yuridis Terhadap Tindak Pidana Kekerasan Fisik", Jurnal Repository Unhas.ac.id, Vol II, No. 3.

M, Wan. A, Rizko, 2014, "Pertanggungjawaban Pidana Terhadap Pelaku Kecelakaan Lalu Lintas yang Mengakibatkan Kematian", Jurnal Skripsi UGM, Vol I, No. 1.

Muhammad Ramadan Kiro, 2015, “Penerapan Unsur Delik Kesengajaan Pada Kecelakaan Lalu Lintas yang mengakibatkan hilangnya nyawa orang lain yang dilakukan oleh orang karena pengaruh alkohol", Jurnal Paper Academia Edu Universitas Hasanuddin, Vol I, No. 2.

Nasrudin, Khairu. 2017, "Penegakan Hukum Secara Terpadu Terhadap Tindak pidana atau tersangka atau tersangka atau tersangka atau tersangka atau tersangka Peredaran Minuman Keras." Jurnal Hukum Khaira Ummah Vol. XII, No. 4.

RLP, Amaretza Lucky, et al, 2014, "Pemidanaan Tindak Pidana Kealpaan yang Menyebabkan Matinya Orang Lain dalam Kecelakaan Lalu Lintas Setelah Keluarnya Undang-Undang Nomor 22 Tahun 2009", Diponegoro Law Jurnal, Vol. III, No. 2.

Wasilah, 2015, "Kebijakan Pemerintah Tentang Larangan Menggunakan Handphone Saat Mengemudi di Jalan Raya", web.unej.ac.id. Vol I, No. 1.

Wijaya, D. A, 2016, "Tinjauan Yuridis Kriminologis Kecelakaan Lalu Lintas Yang Menyebabkan Kematian Dihubungkan Dengan Undang-Undang Nomor 22 Tahun 2009 Tentang Lalu Lintas Dan Angkutan Jalan". Doctoral dissertation, Fakultas Hukum Unpas, Vol. II, No. 4.

\section{Internet}

Kumparan, 2017, "70 Ribu Kecelakaan dalam Setahun Gara-Gara Ponsel", Diakses dari https://kumparan.com/@kumparanoto/70-ribu-kecelakaan-dalam-setahun-gara-gara-ponsel, Pada Tanggal 4 November 2018 Pukul 18.55 WIB.

Ruly Kurniawan, 2019, Menggunakan GPS Boleh, Asal, diakses dari https://oto.detik.com/berita/3899147/gunakan-gps-di-jalan-boleh-asal Pada 30 Mei 2019 Pukul 10.30 WIB.

World Health Organization, diakses dari http://apps.who.int/gho/data/node.main.A997?lang=en, pada Tanggal 10 Mei 2019 Pada Pukul 13.25 WIB. 